\author{
Multidisciplinary \\ SCIENTIFIC JOURNAL OF \\ MARITIME RESEARCH
}

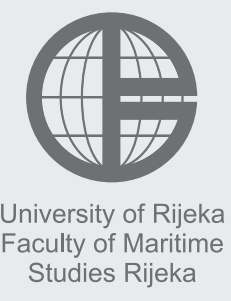

Multidisciplinarni

znanstveni časopis

POMORSTVO

\title{
Efficiency and losses analysis of low-pressure feed water heater in steam propulsion system during ship maneuvering period
}

\author{
Vedran Mrzljak ${ }^{1}$, Igor Poljak ${ }^{2}$, Vedran Medica-Viola ${ }^{3}$ \\ ${ }^{1}$ University of Rijeka, Faculty of Engineering, Department of Thermodynamics and Energy Engineering, Croatia, e-mail: vmrzljak@riteh.hr \\ ${ }^{2}$ Rožići 4/3, 51221 Kostrena, Croatia, e-mail: igor.poljak2@gmail.com \\ ${ }^{3}$ University of Rijeka, Faculty of Humanities and Social Sciences, Department of Polytechnics, Sveučilišna avenija 4, 51000 Rijeka, Croatia, e-mail: \\ vedran.medica@uniri.hr
}

\begin{abstract}
Dominant propulsion systems of today's LNG carriers are steam propulsion systems. Although a number of alternatives are developed, only steam propulsion systems in LNG carriers can fulfill a double function: the function of propulsion and on the other side the combustion of large amounts of BOG (Boil Off Gas) in one or more steam generators. In this paper was provided an analysis of the low-pressure feed water heater, as one of the important components of LNG carrier steam propulsion system. Based on the measured data for all flowing substances throughout the low-pressure feed water heater, it was performed numerical analysis of his energy and exergy efficiency, as well as calculation of energetic and exergetic power losses. The measurements were performed during LNG carrier maneuvering period, what enables insight into the operating parameters of heat exchanger during partial loads of steam propulsion system. From the energetic point of view the low-pressure feed water heater is a nearly perfect balanced device. Analyzed heat exchanger noticeable problems can be seen in exergy efficiency and exergy losses. Exergy represent the maximum available energy potential of any observed component in relation to the environment state. Impact of ambient temperature on the size of the exergy losses has been investigated at the end of conducted analysis. The low-pressure feed water heater is an example of a device which is very well balanced on the one side, even in the conditions of the steam system partial loads, and on the other side his available exergy potential is very poorly exploited.
\end{abstract}

\section{ARTICLE INFO}

Original scientific paper

Received 26 July 2016

Accepted 12 September 2016

Key words:

Low-pressure feed water heater

Efficiency

Heat exchange

Energy and exergy losses

\section{Introduction}

The first LNG carriers were built in the 1960's, and their propulsion systems have been somewhat different than for other ship types. With the aim of efficient, safe, and reliable propulsion, there must also be a means of dealing with the boil off gas (BOG) from the cargo tanks. Propulsion systems available to provide also a solution to the BOG issue were steam propulsion systems which burned the BOG in the steam generators [1]. Nowadays, steam propulsion systems maintain the primacy in the propulsion of LNG carriers, despite numerous alternative propulsion systems [2].

In this paper was analyzed low-pressure feed water heater from LNG carrier steam propulsion system in real exploitative conditions. The low-pressure feed water heater is one of the steam propulsion system constituent components [3], and it is very important to know the movement of its efficiencies as well as energetic and exergetic losses. By knowing the efficiencies and losses of this low-pressure heat exchanger, it is possible to analyze his impact on total energy and exergy balance of the entire steam propulsion system.

LNG carrier on which is mounted analyzed low-pressure feed water heater has main characteristics presented in Table 1.

Table 1 Main characteristics of the analyzed LNG carrier

\begin{tabular}{|l|c|}
\hline Dead weight tonnage & $84.812 \mathrm{DWT}$ \\
\hline Overall length & $288 \mathrm{~m}$ \\
\hline Max breadth & $44 \mathrm{~m}$ \\
\hline Design draft & $9.3 \mathrm{~m}$ \\
\hline Propulsion turbine & Mitsubishi MS40-2 $(29420 \mathrm{~kW})$ \\
\hline
\end{tabular}




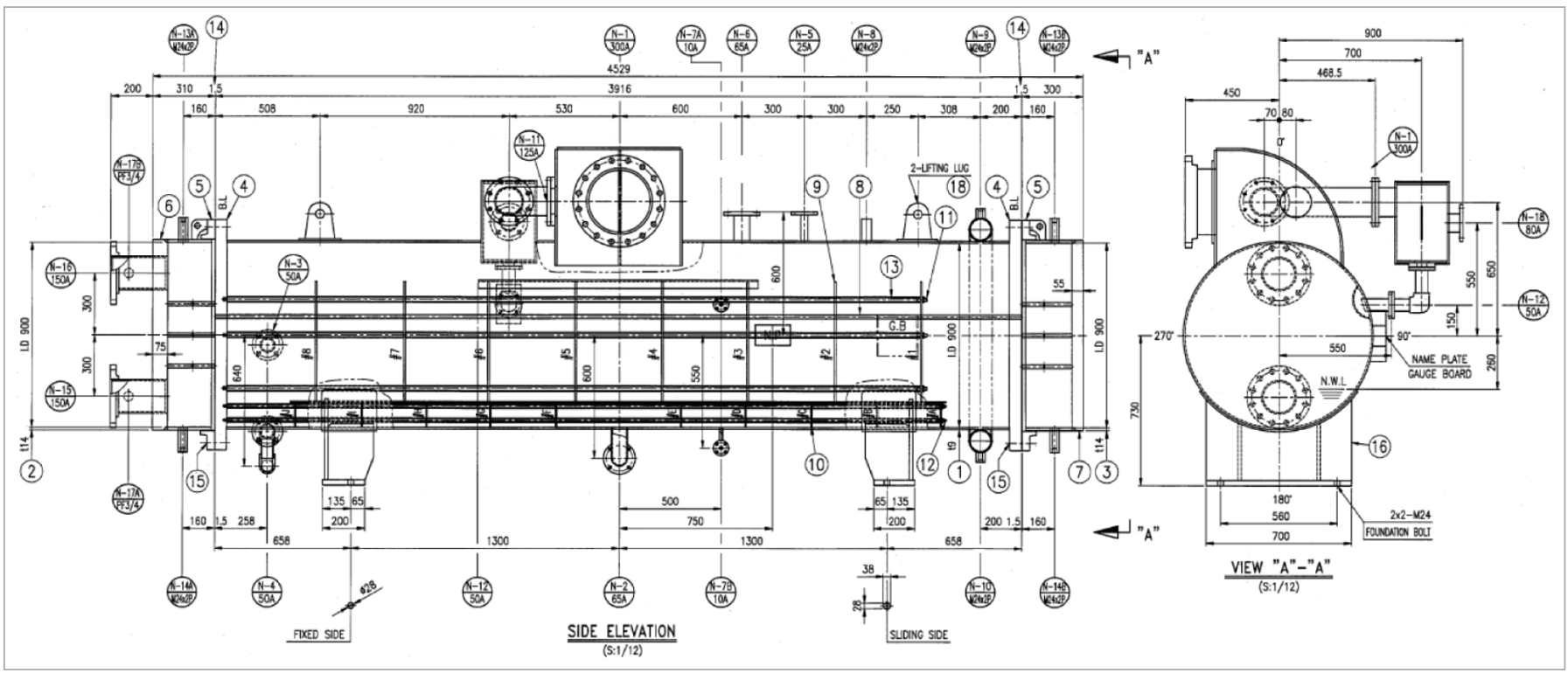

Figure 1 Overall dimensions and cross section of the analyzed low-pressure feed water heater

\section{Low-pressure feed water heater specifications and characteristics}

A low-pressure feed water heater is a typical representative of shell and tube heat exchangers [4]. Feed water is a medium that is heated through a heat exchanger and it has a single entrance (inlet) and single exit (outlet). The feed water is heated with two operating substances. One of them is steam subtracted from the main turbine, at the highest observed steam propulsion system loads. Another medium that heats up the feed water continuously throughout the whole operation period is condensate (inlet). Condensate (inlet) is obtained from the steam subtracted from steam generators (steam propulsion system has two mirror oriented steam generators). Subtracted steam passes first through the air heaters of steam generators, condenses in them and formed condensate is used in low-pressure feed water heater as the heating medium. Last operating fluid is condensate (outlet) generated from condensate (inlet) and the steam subtracted from the main turbine (which condenses into low-pressure feed water heater).

The main constructional and operating parameters of the low-pressure feed water heater were presented in Table 2, according to the producer specifications [5].

Overall dimensions and cross section of the analyzed low-pressure feed water heater are presented in Figure 1. As for all other heat exchangers, also in this case of lowpressure feed water heater is necessary regular control and maintenance during operation.

\section{Efficiency and losses numerical model}

For the low-pressure feed water heater, all the essential elements of numerical model were presented in Figure 2 . The required enthalpies and entropies were calculated from measured pressures and temperatures for every flowing substance by using Nist REFPROP software [6].

Table 2 Main constructional and operating parameters of the analyzed low-pressure feed water heater

\begin{tabular}{|l|c|c|}
\hline \multicolumn{1}{|c|}{ Low-pressure feed water heater } & Shell side & Tube side \\
\hline Maximum flow rate $(\mathrm{kg} / \mathrm{h})$ & 8303 & 88617 \\
\hline Maximum operating pressure $(\mathrm{MPa})$ & 0.159 (steam) & 0.834 \\
\hline Number of passes & 2 zones & 6 passes \\
\hline Velocity (m/s) & - & 1.34 at $78^{\circ} \mathrm{C}$ \\
\hline Maximum pressure drop (MPa) & - & 0.0373 \\
\hline Maximum corrosion allowance $(\mathrm{mm})$ & 1.6 & 1.6 \\
\hline Tube quantity & - & 450 \\
\hline Tube outer diameter $(\mathrm{mm})$ & - & 19.0 \\
\hline Shell inner/outer diameter $(\mathrm{mm})$ & $900 / 918$ & - \\
\hline Material & Carbon Steel & Al-Brass \\
\hline
\end{tabular}

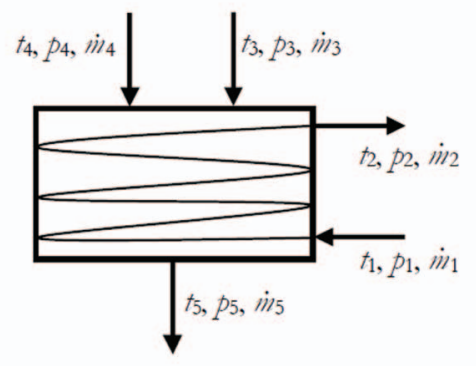

$$
\begin{aligned}
& 1=\text { feed water inlet } \\
& 2=\text { feed water outlet } \\
& 3=\text { steam inlet } \\
& 4=\text { condensate inlet } \\
& 5=\text { condensate outlet }
\end{aligned}
$$

Figure 2 Low-pressure feed water heater symbol and operating parameters used in the numerical model 
Mathematical definition of the low-pressure feed water heater, according to Figure 2, demands three balances, which is necessary for energy and exergy efficiency and losses calculation. These balances are mass flow balance, energy balance and exergy balance [7].

\section{- Mass flow balance}

$$
\begin{aligned}
& \dot{m}_{1}=\dot{m}_{2} \\
& \dot{m}_{3}+\dot{m}_{4}=\dot{m}_{5}
\end{aligned}
$$

\section{- Energy balance (according to [8] and [9])}

Energetic power input:

$$
E_{e n, I N}=\dot{m}_{3} \cdot h_{3}+\dot{m}_{4} \cdot h_{4}-\dot{m}_{5} \cdot h_{5}
$$

Energetic power output:

$$
E_{\text {en, OUT }}=\dot{m}_{1} \cdot\left(h_{2}-h_{1}\right)
$$

Energetic power loss:

$$
\begin{aligned}
& E_{e n, P L}=E_{e n, I N}-E_{e n, \text { OUT }}=\dot{m}_{1} \cdot h_{1}+\dot{m}_{3} \cdot h_{3}+\dot{m}_{4} \cdot h_{4}- \\
& -\dot{m}_{1} \cdot h_{2}-\dot{m}_{5} \cdot h_{5}
\end{aligned}
$$

The energy efficiency of the low-pressure feed water heater was obtained by using an equation:

$$
\eta_{e n}=\frac{E_{e n, O U T}}{E_{e n, \mathrm{~N}}}=\frac{\dot{m}_{1} \cdot\left(h_{2}-h_{1}\right)}{\dot{m}_{3} \cdot h_{3}+\dot{m}_{4} \cdot h_{4}-\dot{m}_{5} \cdot h_{5}}
$$

\section{- Exergy balance (according to [10] and [11])}

Exergetic power input:

$$
E_{e x, I N}=\dot{m}_{3} \cdot \varepsilon_{3}+\dot{m}_{4} \cdot \varepsilon_{4}-\dot{m}_{5} \cdot \varepsilon_{5}
$$

Exergetic power output:

$$
E_{\text {ex, OUT }}=\dot{m}_{1} \cdot\left(\varepsilon_{2}-\varepsilon_{1}\right)
$$

Exergetic power loss (exergy destruction):

$$
\begin{aligned}
& E_{e x, P L}=E_{e x, I N}-E_{e x, \text { OUT }}=\dot{m}_{1} \cdot \varepsilon_{1}+\dot{m}_{3} \cdot \varepsilon_{3}+\dot{m}_{4} \cdot \varepsilon_{4}- \\
& -\dot{m}_{1}^{\prime} \varepsilon_{2}-\dot{m}_{5} \cdot \varepsilon_{5}
\end{aligned}
$$

The exergy efficiency of the low-pressure feed water heater was obtained by using an equation:

$$
\eta_{e x}=\frac{E_{e x, O U T}}{E_{e x, I N}}=\frac{\dot{m}_{1} \cdot\left(\varepsilon_{2}-\varepsilon_{1}\right)}{\dot{m}_{3} \cdot \varepsilon_{3}+\dot{m}_{4} \cdot \varepsilon_{4}-\dot{m}_{5} \cdot \varepsilon_{5}}
$$

The environment state (dead state) in the engine room of analyzed LNG carrier during a measurement period was:

$$
\begin{array}{ll}
\text { - Pressure: } & p_{0}=0.1 \mathrm{MPa}, \\
\text { - Temperature: } & T_{0}=25^{\circ} \mathrm{C}=298.15 \mathrm{~K} .
\end{array}
$$

\section{Measurements - equipment and results}

\begin{tabular}{|c|c|}
\hline $\begin{array}{l}\text { Feed water mass flow } \\
\text { (inlet) }\end{array}$ & $\begin{array}{l}\text { Promass } 80 \mathrm{~F} \text { - Coriolis Mass Flow } \\
\text { Measuring System [12] }\end{array}$ \\
\hline $\begin{array}{l}\text { Feed water pressure } \\
\text { (inlet) }\end{array}$ & $\begin{array}{l}\text { Yamatake JTG940A - Pressure Transmitter } \\
\text { [13] }\end{array}$ \\
\hline $\begin{array}{l}\text { Feed water temperature } \\
\text { (inlet) }\end{array}$ & $\begin{array}{l}\text { Greisinger GTF 401-Pt100 - Immersion } \\
\text { probe [14] }\end{array}$ \\
\hline $\begin{array}{l}\text { Feed water pressure } \\
\text { (outlet) }\end{array}$ & $\begin{array}{l}\text { Yamatake JTG940A - Pressure Transmitter } \\
\text { [13] }\end{array}$ \\
\hline $\begin{array}{l}\text { Feed water temperature } \\
\text { (outlet) }\end{array}$ & $\begin{array}{l}\text { Greisinger GTF 401-Pt100 - Immersion } \\
\text { probe [14] }\end{array}$ \\
\hline Steam mass flow & $\begin{array}{l}\text { Yamatake JTD920A - Differential Pressure } \\
\text { Transmitter [15] }\end{array}$ \\
\hline Steam pressure & $\begin{array}{l}\text { Yamatake JTG940A - Pressure Transmitter } \\
\text { [13] }\end{array}$ \\
\hline Steam temperature & $\begin{array}{l}\text { Greisinger GTF 401-Pt100 - Immersion } \\
\text { probe [14] }\end{array}$ \\
\hline $\begin{array}{l}\text { Condensate mass flow } \\
\text { (inlet) }\end{array}$ & $\begin{array}{l}\text { Promass } 80 \mathrm{~F} \text { - Coriolis Mass Flow } \\
\text { Measuring System [12] }\end{array}$ \\
\hline $\begin{array}{l}\text { Condensate pressure } \\
\text { (inlet) }\end{array}$ & $\begin{array}{l}\text { Yamatake JTG940A - Pressure Transmitter } \\
\text { [13] }\end{array}$ \\
\hline $\begin{array}{l}\text { Condensate temperature } \\
\text { (inlet) }\end{array}$ & $\begin{array}{l}\text { Greisinger GTF 601-Pt100 - Immersion } \\
\text { probe [14] }\end{array}$ \\
\hline $\begin{array}{l}\text { Condensate pressure } \\
\text { (outlet) }\end{array}$ & $\begin{array}{l}\text { Yamatake JTG940A - Pressure Transmitter } \\
\text { [13] }\end{array}$ \\
\hline $\begin{array}{l}\text { Condensate temperature } \\
\text { (outlet) }\end{array}$ & $\begin{array}{l}\text { Greisinger GTF 601-Pt100 - Immersion } \\
\text { probe [14] }\end{array}$ \\
\hline
\end{tabular}

The measurement results were obtained by using existing measuring equipment already mounted on all the components of the steam propulsion system. Control and maintenance system (provided by manufacturer on the analyzed LNG carrier) is very important on such propulsion systems because it allows control and regulation of all operating parameters for each constituent component.

List of used measuring equipment is presented in Table 3. Measuring equipment details as well as accuracy ranges of any used measuring device can be found on producer web sites.

Table 3 List of used measuring equipment

Measurement results for all fluid streams throughout the low-pressure feed water heater are presented in Table 4. All operating parameters were measured in relation to propulsion propeller revolutions. Propulsion propeller revolutions are directly proportional to the steam propulsion system load - by increasing in propulsion propeller revolutions also increases the steam system load. On the analyzed LNG carrier during exploitation, maximum steam system load occurs at propulsion propeller revolutions $95 \mathrm{~min}^{-1}$ (full speed operation mode). 
Table 4 Measurement results for all stream flows throughout the low-pressure feed water heater

\begin{tabular}{|c|c|c|c|c|c|c|c|c|c|c|c|c|c|}
\hline $\begin{array}{c}\text { Propulsion } \\
\text { propeller } \\
\text { revolutions } \\
\left(\mathrm{min}^{-1}\right)\end{array}$ & $\begin{array}{c}\text { Feed } \\
\text { water } \\
\text { (inlet) } \\
\text { mass } \\
\text { flow } \\
(\mathrm{kg} / \mathrm{h})\end{array}$ & $\begin{array}{l}\text { Feed } \\
\text { water } \\
\text { (inlet) } \\
\text { press. } \\
\text { (MPa) }\end{array}$ & $\begin{array}{c}\text { Feed } \\
\text { water } \\
\text { (inlet) } \\
\text { temp. } \\
\left({ }^{\circ} \mathrm{C}\right)\end{array}$ & $\begin{array}{c}\text { Feed } \\
\text { water } \\
\text { (outlet) } \\
\text { press. } \\
\text { (MPa) }\end{array}$ & $\begin{array}{c}\text { Feed } \\
\text { water } \\
\text { (outlet) } \\
\text { temp. } \\
\left({ }^{\circ} \mathrm{C}\right)\end{array}$ & $\begin{array}{c}\text { Steam } \\
\text { mass } \\
\text { flow } \\
(\mathrm{kg} / \mathrm{h})\end{array}$ & $\begin{array}{l}\text { Steam } \\
\text { press. } \\
\text { (MPa) }\end{array}$ & $\begin{array}{l}\text { Steam } \\
\text { temp. } \\
\left({ }^{\circ} \mathrm{C}\right)\end{array}$ & $\begin{array}{c}\text { Cond. } \\
\text { (inlet) } \\
\text { mass } \\
\text { flow } \\
(\mathrm{kg} / \mathrm{h})\end{array}$ & $\begin{array}{l}\text { Cond. } \\
\text { (inlet) } \\
\text { press. } \\
\text { (MPa) }\end{array}$ & $\begin{array}{l}\text { Cond. } \\
\text { (inlet) } \\
\text { temp. } \\
\left({ }^{\circ} \mathrm{C}\right)\end{array}$ & $\begin{array}{c}\text { Cond. } \\
\text { (outlet) } \\
\text { press. } \\
\text { (MPa) }\end{array}$ & $\begin{array}{c}\text { Cond. } \\
\text { (outlet) } \\
\text { temp. } \\
\left({ }^{\circ} \mathrm{C}\right)\end{array}$ \\
\hline 25.00 & 28179 & 0.75 & 44.0 & 0.75 & 51.5 & 0 & - & - & 4134 & 0.549 & 155.38 & 0.549 & 102.00 \\
\hline 34.33 & 31448 & 0.75 & 43.0 & 0.75 & 52.5 & 0 & - & - & 4117 & 0.452 & 148.06 & 0.452 & 73.00 \\
\hline 56.65 & 35884 & 0.75 & 58.0 & 0.75 & 66.6 & 0 & - & - & 4572 & 0.549 & 155.38 & 0.549 & 86.00 \\
\hline 61.45 & 45127 & 0.75 & 56.0 & 0.75 & 63.3 & 0 & - & - & 5066 & 0.548 & 155.31 & 0.548 & 89.00 \\
\hline 62.52 & 44671 & 0.75 & 56.0 & 0.75 & 62.9 & 0 & - & - & 4977 & 0.551 & 155.52 & 0.551 & 93.00 \\
\hline 63.55 & 47731 & 0.75 & 55.0 & 0.75 & 62.0 & 0 & - & - & 5141 & 0.548 & 155.31 & 0.548 & 90.00 \\
\hline 68.66 & 54751 & 0.75 & 53.0 & 0.75 & 59.0 & 0 & - & - & 5489 & 0.548 & 155.31 & 0.548 & 95.00 \\
\hline 69.49 & 56137 & 0.75 & 53.0 & 0.75 & 58.8 & 0 & - & - & 5526 & 0.549 & 155.38 & 0.549 & 96.00 \\
\hline 70.37 & 57725 & 0.75 & 53.0 & 0.75 & 58.7 & 0 & - & - & 5552 & 0.550 & 155.45 & 0.550 & 96.00 \\
\hline 71.03 & 58354 & 0.75 & 52.0 & 0.75 & 57.4 & 0 & - & - & 5406 & 0.551 & 155.52 & 0.551 & 97.00 \\
\hline 73.09 & 63486 & 0.75 & 51.0 & 0.75 & 59.0 & 320 & 0.0940 & 168.0 & 5560 & 0.551 & 155.52 & 0.094 & 97.88 \\
\hline 74.59 & 65472 & 0.75 & 52.0 & 0.75 & 60.0 & 424 & 0.0970 & 156.0 & 4996 & 0.539 & 154.68 & 0.097 & 98.75 \\
\hline 76.56 & 70211 & 0.75 & 51.0 & 0.75 & 62.0 & 855 & 0.1004 & 169.0 & 5131 & 0.531 & 154.11 & 0.100 & 99.60 \\
\hline 78.41 & 76328 & 0.75 & 51.0 & 0.75 & 63.0 & 1104 & 0.1008 & 167.0 & 5122 & 0.541 & 154.82 & 0.101 & 99.88 \\
\hline 79.46 & 75216 & 0.75 & 51.0 & 0.75 & 64.0 & 1279 & 0.1100 & 160.0 & 4724 & 0.549 & 155.38 & 0.110 & 102.00 \\
\hline
\end{tabular}

\section{Results and discussion}

Low-pressure feed water heater energy and exergy efficiency change is presented in Figure 3.

The energy efficiency of this heat exchanger is very high (above $90 \%$ ) even at lowest steam system loads. A noticeable jump in energy efficiency can be seen at propulsion propeller revolutions of $73.09 \mathrm{~min}^{-1}$. That is the moment in which steam from the main turbine starts to enter in the heat exchanger. By increasing the steam system load, the amount of steam that enters in the lowpressure feed water heater increases, causing an increase in the energy efficiency. At highest observed steam system loads energy efficiency reaches the level which is very close to $100 \%$.

Exergy efficiency of the observed heat exchanger is much lower than the energy efficiency. During the lowest observed steam system loads exergy efficiency amounts $27-40 \%$, with further growth potential during steam system load increasing. Like in energy efficiency, also in the case of exergy efficiency the noticeable jump was recorded at propulsion propeller revolutions of $73.09 \mathrm{~min}^{-1}$, at a moment in which steam from the main turbine starts to enter in the heat exchanger. Even at the highest steam system loads exergy efficiency of low-pressure feed water heater does not exceed the limit of $50 \%$.

Pursuant to the above, from Figure 3 it can be concluded that the observed low-pressure feed water heater is energetic almost ideally balanced. On the other side, exergy potential, according to the environment state, is quite poorly exploited, even at the highest considered steam propulsion system loads.

A good energetic balance of low-pressure feed water heater can be seen in his energetic power input and output change, for various propulsion propeller revolutions, Figure 4.

At lower steam system loads, energetic power input and output does not exceed the limit of $400 \mathrm{~kW}$. At the moment of steam entrance into analyzed heat exchanger energetic power input and output rises rapidly and they achieved almost $1400 \mathrm{~kW}$ at the highest observed propulsion propeller revolutions. 


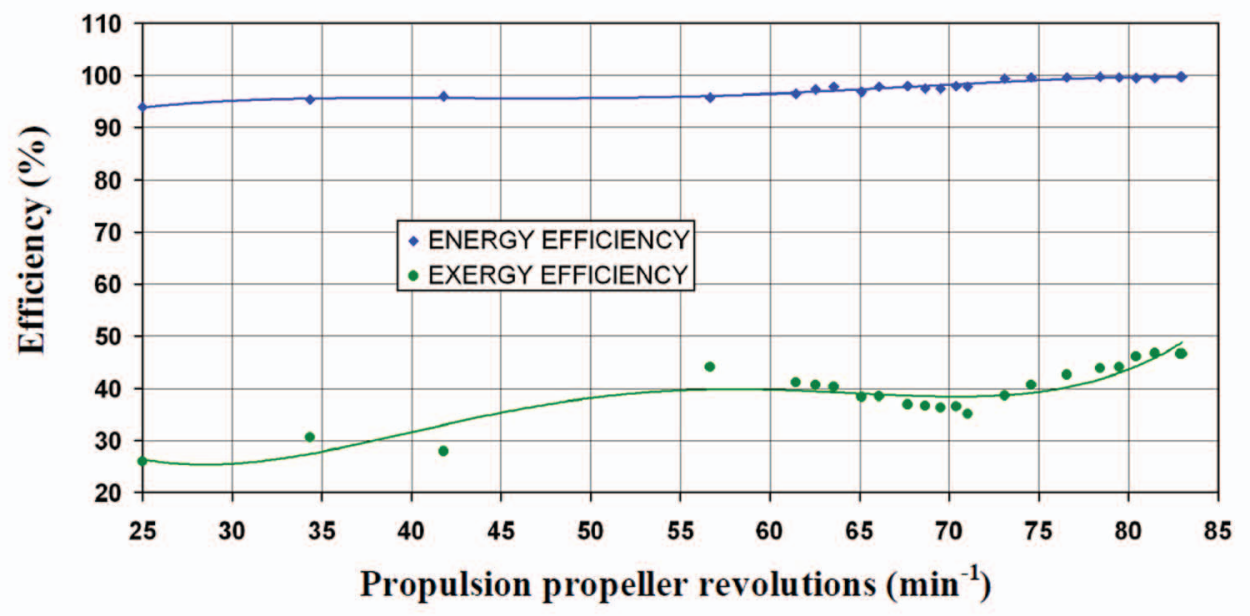

Figure 3 Energy and exergy efficiency change of low-pressure feed water heater

The difference between trend-lines of energetic power input and output represent energetic power losses in the analyzed heat exchanger. On the lower steam system loads that difference has a small value but is still visible, Figure 4. At higher propulsion propeller revolutions, during the steam entrance from the main turbine, the difference in the trend-lines between the energetic power input and output is almost invisible.

From Figure 4 it can be concluded that steam entrance into the low-pressure feed water heater causes a further reduction in the already low energy losses, while the amount of heat exchanged significantly increases.

The size of energetic power losses of low-pressure feed water heater is presented in Figure 5. During the whole observed operating period energetic power losses are very small and they do not exceed $17 \mathrm{~kW}$, even at the lowest propulsion propeller revolutions, where, due to the start of the steam system operation, higher energetic losses usually can be expected. At the time when steam from the main turbine enters in the analyzed heat exchanger, the energetic power losses were falling drastically and at the highest observed propulsion propeller revolutions they do not exceed $5 \mathrm{~kW}$.

Energetic power losses are inversely proportional to energy efficiency for analyzed low-pressure feed water heater. For lowest values of energy efficiency, energetic power losses have the highest values and vice versa at higher energy efficiency values energetic power losses are the smallest, almost negligible for the observed heat exchanger.

Exergetic power input and output trend of change for analyzed heat exchanger during all observed propulsion propeller revolutions can be seen in Figure 6 .

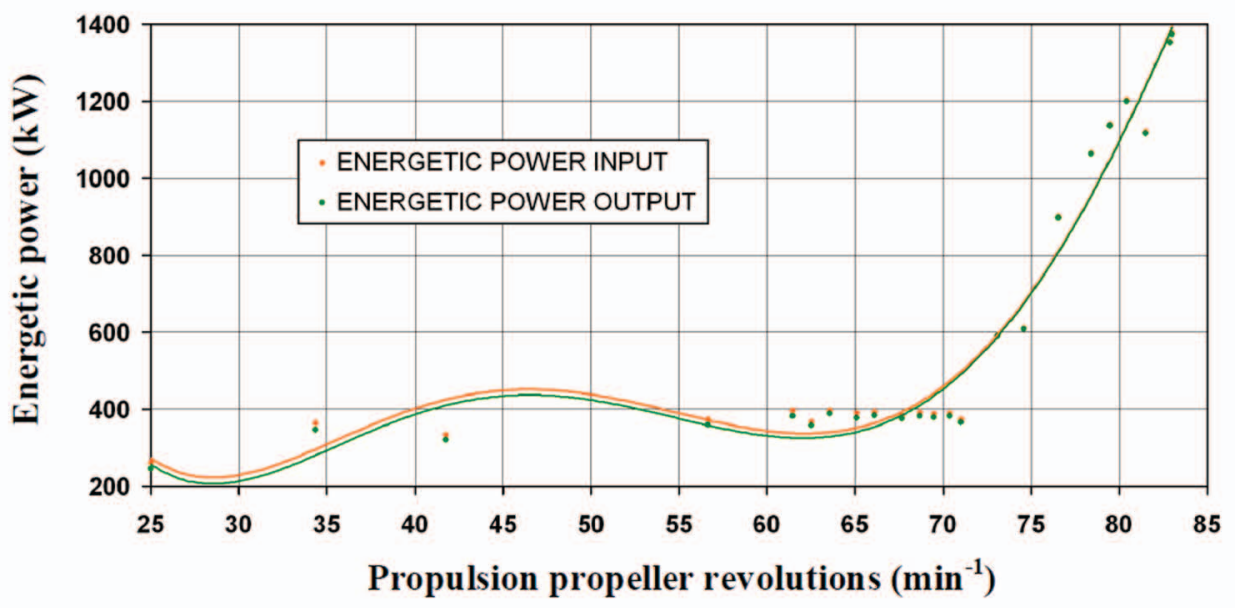

Figure 4 Energetic power input and output change during various steam propulsion system loads for observed heat exchanger 


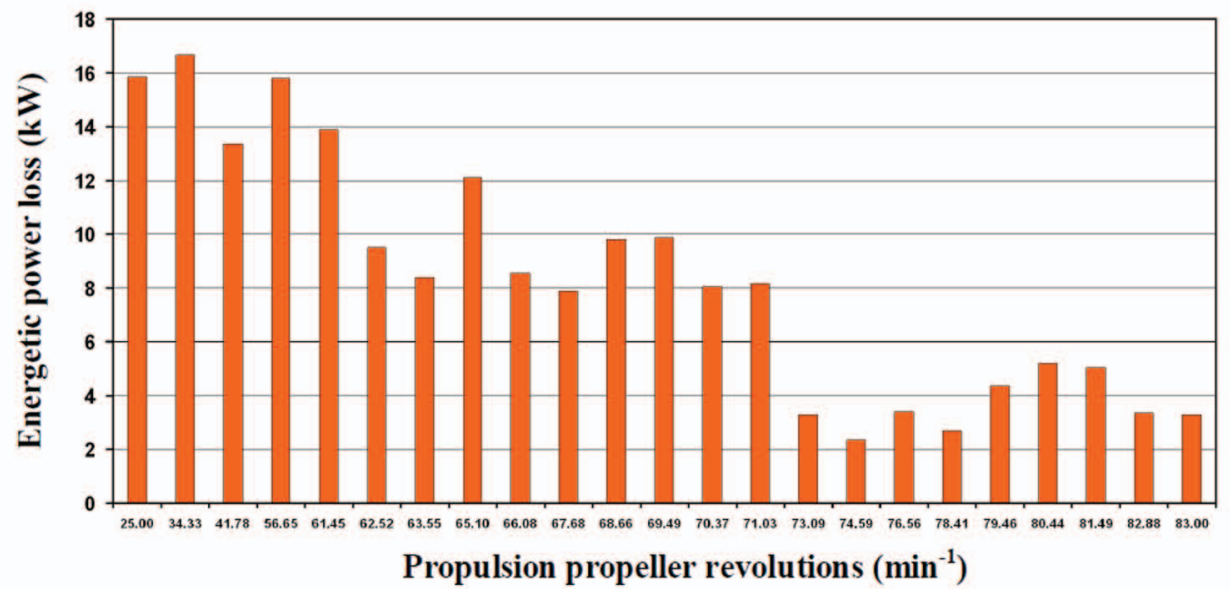

Figure 5 Energetic power losses for observed low-pressure feed water heater

Trends of change for both exergetic power input and output are almost the same. At lower steam propulsion system loads exergetic power input and output are almost constant. Strong growth of exergetic power input and output is occurring at the moment of steam entrance into the low-pressure feed water heater. It is necessary to notice that the increase in exergetic power input is sharper than the increase in exergetic power output at highest observed propulsion propeller revolutions. In that operational area the steam brings a significantly greater amount of exergy into the heat exchanger compared to exergy that is transferred to the feed water. This fact has a great influence on the exergetic power losses.

The difference in the trend-lines between exergetic power input and exergetic power output is quite large, so the general conclusion is that, unlike the energetic point of view, analyzed low-pressure feed water heater is poorly exergetic exploited. Confirmation of this conclusion is evident in Figure 3, which displays the movement of exergy efficiency.

Exergetic power losses, Figure 7, have the opposite movement trend compared to energetic power losses. At lower propulsion propeller revolutions exergetic power losses are almost constant and amounts around $60 \mathrm{~kW}$. When steam starts to enter into the analyzed heat exchanger, at propulsion propeller revolutions of 73.09 min $^{-1}$, exergetic power losses started to grow rapidly. Maximum exergetic power losses occur at the highest observed steam system loads and amounts around $160 \mathrm{~kW}$.

Steam entrance into the analyzed heat exchanger, from the exergetical point of view, causes one good and one bad phenomenon. Bad phenomenon is that steam entrance

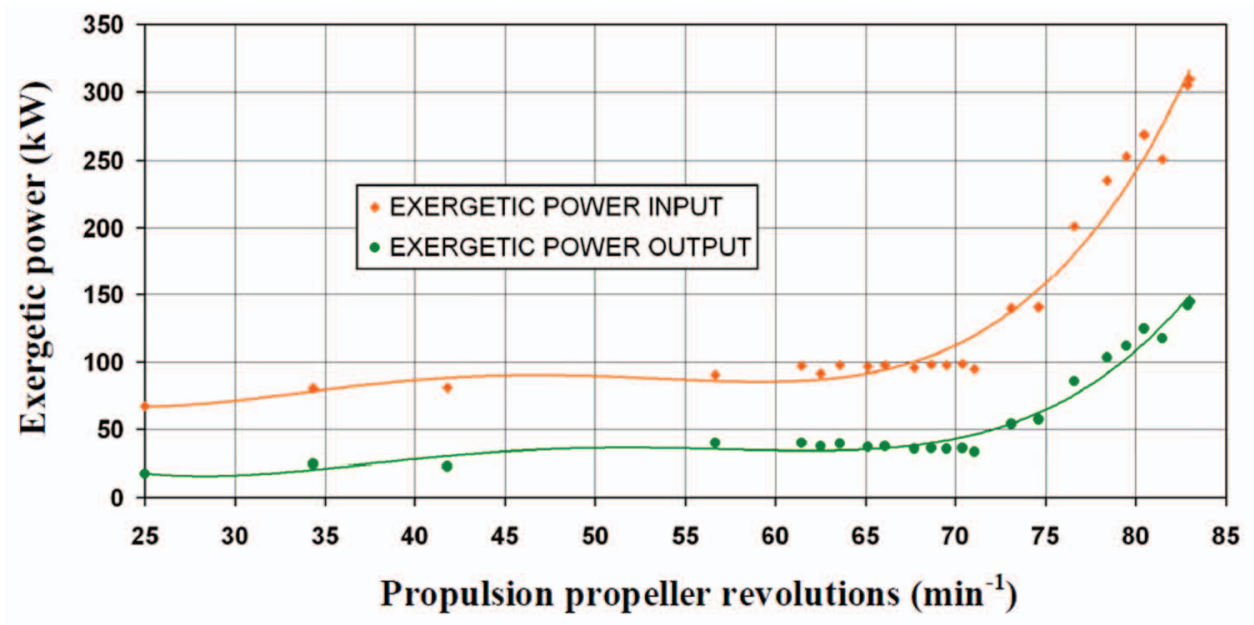

Figure 6 Exergetic power input and output change during various steam propulsion system loads for observed heat exchanger 


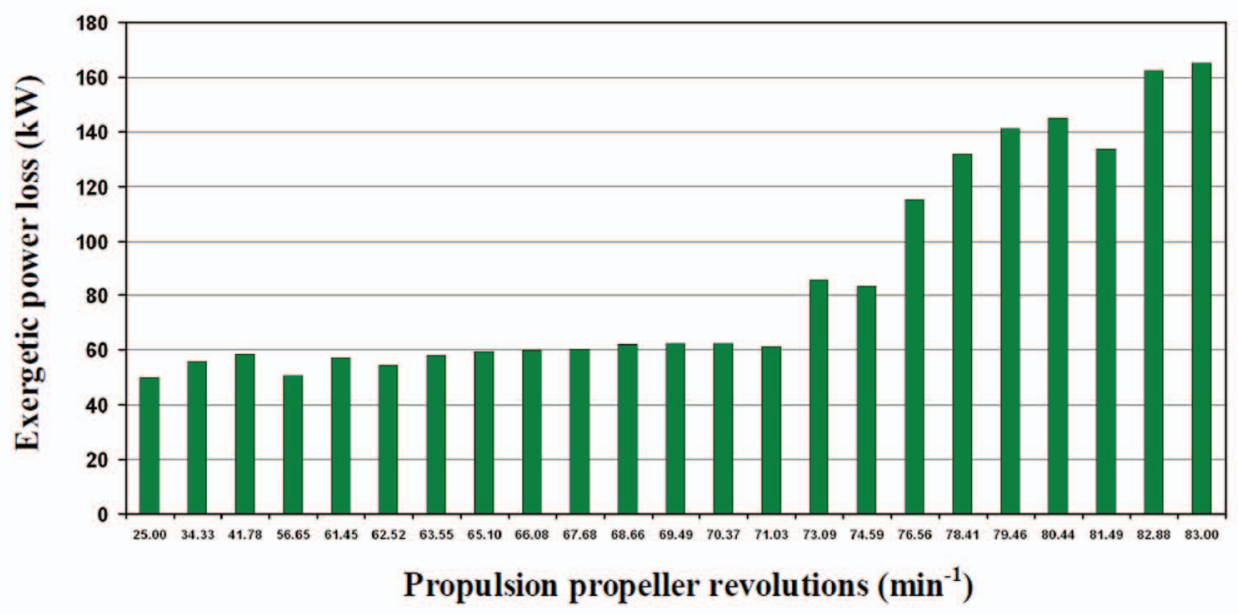

Figure 7 Exergetic power losses for observed low-pressure feed water heater

causes an increase in the exergetic power losses, which are already high in the analyzed heat exchanger. Good phenomenon of steam entrance is an increase in exergy efficiency of the low-pressure heat exchanger. One of the options for future research of this heat exchanger is certainly the cost-effective analysis - whether the increase in exergy efficiency can compensate the increase in exergetic power losses.

Exergetic power losses (exergy destruction) can be reduced in different ways. Most of them are very complex and involves changes in various operating parameters for any observed heat exchanger. One of the acceptable and easily feasible models of exergetic power loss reduction is the change in the environment temperature, in particular case of the ship engine room, in which is located analyzed low-pressure feed water heater.
Figure 8 presents the change in exergy destruction for low-pressure feed water heater during all observed steam system loads. Presented trend-lines provide the best insight into the mode and intensity of exergy destruction reduction. Middle trend-line presents the change in exergy destruction for analyzed heat exchanger during the real exploitation conditions, in which the engine room temperature was $25^{\circ} \mathrm{C}$. With the increase of temperature in the ship engine room from $25^{\circ} \mathrm{C}$ to $40^{\circ} \mathrm{C}$, exergetic power losses will increase, while with reducing the temperature from $25^{\circ} \mathrm{C}$ to $10^{\circ} \mathrm{C}$ exergetic power losses will decrease.

Also in this case one of the areas of future research would be to study the economic impact of temperature reduction in ship engine room on exergetic power loss reduction. In this analysis, it would be necessary to include not only the analyzed low-pressure feed water heater, but

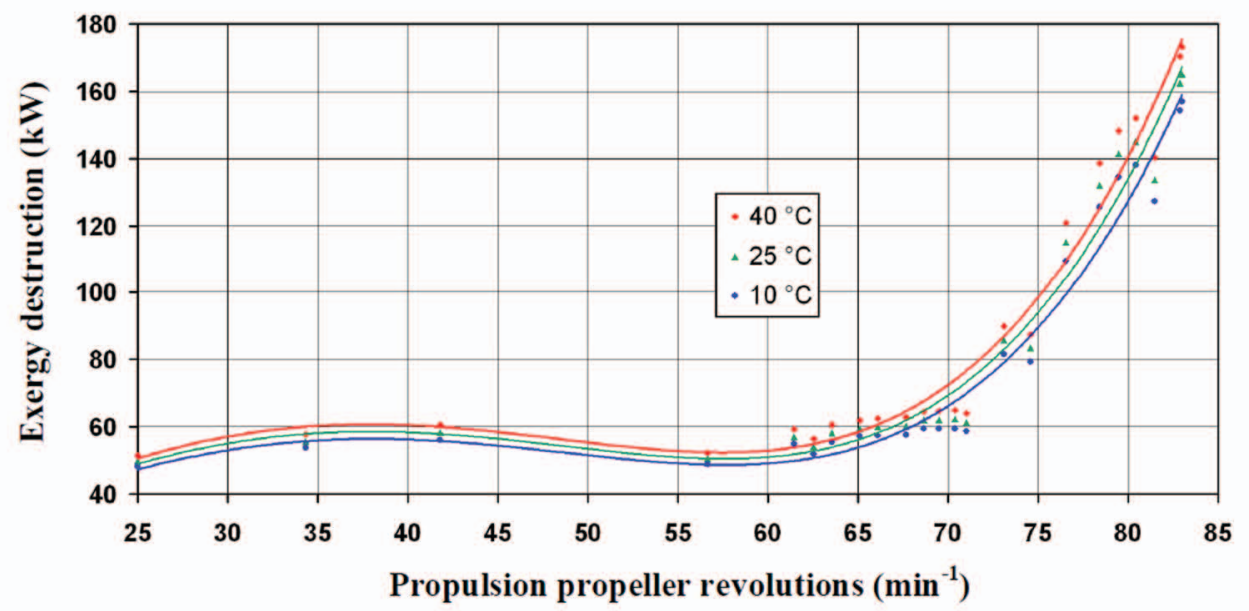

Figure 8 Exergy destruction change of low-pressure feed water heater for various environmental temperatures 
also all the other devices that are an integral part of steam propulsion system.

\section{Conclusions}

In this paper was presented energetic and exergetic analysis of the low-pressure feed water heater, an integral part of steam propulsion system mounted on the analyzed LNG carrier.

Measured results of all flow streams throughout the low-pressure feed water heater were performed in ship exploitation during maneuvering period. On that way an insight into the efficiencies and losses of the analyzed heat exchanger during transient steam propulsion system operating conditions was gained.

From the energetic point of view, the low-pressure feed water heater is almost perfect balanced device that achieves the highest values of energy efficiency and the lowest energetic power losses on the highest observed steam system loads. Also at the lower steam system loads this heat exchanger reaches highly energy efficiency values on the one side and more than sufficient low energetic power losses on the other.

Exergy efficiency of analyzed heat exchanger varies between $27 \%$ at the lowest observed steam system loads, up to approximately $50 \%$ at the highest observed steam system loads. From the exergetical point of view, this heat exchanger is insufficiently exploited and a practical solution for increasing its exergy efficiency should be founded.

Low heat exchanger exergy efficiency causes high exergetic power losses. Influence of steam, which enters into the heat exchanger as additional heating medium at higher steam system loads, is twofold. At the same time, steam flow causes an increase in exergy efficiency with simultaneous increase in exergetic power losses.

Finally, it can be concluded that the energy flows of the analyzed low-pressure feed water heater were almost perfectly adjusted, but the problems are visible in the usability of the exergy potential due to the environment state.

\section{Acknowledgment}

The authors would like to extend their appreciations to the main office of the analyzed LNG carrier ship-owner, for all the help during exploitation measurements and for ceded measuring equipment.

\section{NOMENCLATURE}

\section{Abbreviations:}

cond. condensate

press. pressure

temp. temperature

\section{Latin Symbols:}

$\begin{array}{ll}E & \text { power, } \mathrm{kW} \\ h & \text { specific enthalpy, } \mathrm{kJ} / \mathrm{kg} \\ \dot{m} & \text { mass flow, } \mathrm{kg} / \mathrm{s} \\ p & \text { pressure, } \mathrm{MPa} \\ T & \text { temperature, }{ }^{\circ} \mathrm{C}\end{array}$

Greek symbols:

$\begin{array}{ll}\eta & \text { efficiency } \\ \varepsilon & \text { specific exergy, } \mathrm{kJ} / \mathrm{kg}\end{array}$

Subscripts:

0 dead state (environment state)

en energetic

ex exergetic

IN input

OUT output

PL power loss

\section{References}

[1] Christer Browman, Karl Briers: LNG Propulsion Alternatives, http://www.herbert.com/wp-content/uploads/2010/03/ LNG-Propulsion-Alternatives-CMA.pdf (last visited: 01.07.2016).

[2] LNG World Shipping Journal, September/October, 2007.

[3] Moran, M. J., Shapiro, H. N.: Fundamentals of engineering thermodynamics, $6^{\text {th }}$ edition, John Wiley \& Sons, Hoboken, NJ, 2008.

[4] Kakac, S., Liu, H., Pramuanjaroenkij, A.: Heat Exchangers Selection, Rating, and Thermal Design, Third edition, CRC Press, Taylor \& Francis Group, 2012.

[5] $1^{\text {st }}$ Feed Water Heater - instruction and maintenance manual, DongHwa Entec, Pusan, Korea, internal ship documentation, 2006.

[6] Lemmon, E. W., Huber, M. L., McLinden, M. O.: NIST Reference Fluid Thermodynamic and Transport Properties-REFPROP, Version 8.0, User's Guide, Colorado, 2007.

[7] Ahmadi, G.R., Toghraie, D.: Energy and exergy analysis of Montazeri Steam Power Plant in Iran, Renewable and Sustainable Energy Reviews 56, pp. 454-463, 2016 (doi: 10.1016/j.rser.2015.11.074).

[8] Kaushik, S.C., Reddy, V.S., Tyagi, S.K.: Energy and exergy analyses of thermal power plants: A review, Renewable and Sustainable Energy Reviews 15, p. 1857-1872, 2011 (doi: 10.1016/j.rser.2010.12.007).

[9] Aljundi, I. H.: Energy and exergy analysis of a steam power plant in Jordan, Applied Thermal Engineering 29, pp. 324328, 2009 (doi: 10.1016/j.applthermaleng.2008.02.029).

[10] Ray, T.K., Datta, A., Gupta, A., Ganguly, R.: Exergy-based performance analysis for proper $0 \& M$ decisions in a steam power plant, Energy Conversion and Management 51, pp. 1333-1344, 2010 (doi: 10.1016/j.enconman.2010.01.012).

[11] Hafdhi, F., Khir, T., Ben Yahyia, A., Ben Brahim, A.: Energetic and exergetic analysis of a steam turbine power plant in an existing phosphoric acid factory, Energy Conversion and Management 106, pp. 1230-1241, 2015 (doi: 10.1016/j. enconman.2015.10.044)

[12] h t t p s : / / p o r t a l. endres s . c o m / w a $001 /$ dla/5000275/1921/000/00/TI101DEN_1009.pdf (last visited: 12.07.2016).

[13] http://www.industriascontrolpro.com/fichat/SS2DST400-0100.pdf (last visited: 12.07.2016).

[14] https://www.greisinger.de/files/upload/en/produkte/kat/ k16_011_EN_oP.pdf (last visited: 14.07.2016).

[15] http://www.krtproduct.com/krt_Picture/sample/1_ spare\%20part/yamatake/Fi_ss01/SS2-DST100-0100.pdf (last visited: 14.07.2016). 